\title{
The Pragmatic Strategies of Concealment in Bush's Speech of Announcing War Against Iraq in 2003
}

\author{
Rana Naji Aziz ${ }^{1}$ \& Abbas Deygan Darweesh Al-Duleimi² \\ ${ }^{1}$ Department of Tourism, College of Tourism Sciences, AL-Mustansiriyah University, Iraq \\ ${ }^{2}$ Department of English, College of Education for Human Sciences, University of Babylon, Iraq \\ Correspondence: Rana Naji, Department of Tourism, College of Tourism Sciences, AL-Mustansiriyah University, \\ Iraq. E-mail: rananaji99@uomustansiriyah.edu.iq
}

\author{
Received: January 6, 2018 Accepted: April 17, 2018 Online Published: April 24, 2018 \\ doi:10.5539/ijel.v8n4p216 URL: https://doi.org/10.5539/ijel.v8n4p216
}

\begin{abstract}
Concealment is the act of intentionally withholding information for some purposes. It is the mode of using language to hide information and intentions. The current study aims at finding out the pragmatic aspects of concealment. In accordance with the aim of the paper, it is hypothesized that the phenomena of concealment basically targets achieving persuasion and self- defense. The most important findings yielded by the analysis reveal that the main pragmatic aspects utilized in issuing concealment are breaching Grice's maxims, pragma-rhetorical devices, deictic expressions and positive politeness strategies.
\end{abstract}

Keywords: concealment, pragmatic strategies, breaching maxims, withholding information

\section{Introduction}

Language is used as a means of communication through which people can achieve different aims. This means of communication is used to interact and deliver messages of different information and intentions. However, language can also be used as a medium of concealing and hiding these information or intentions. As such, concealment is the strategy of using language to conceal facts or intentions.

Concealment as a mode of speaking, According to Clark (1992), is adopted to hide information, or intentions, from other over-hearers, it is the tactic used to hide information from a third party (ibid, p. 275). Bellebaum (1992, p. 88, cited in Schröter, 2013) asserts that "being silent" is not necessarily indicating concealing something, to him "Sometimes many words are required to keep a secret". Within the same perspective of silence, Schröter (2013, p. 16) characterizes concealment as a form of silence but concealment is rather wordy. According to her (ibid), concealment is a silence but in the form of verbal communication. One of the main issues in the rationale for current study is the opportunity to study concealment as a pragmatic phenomenon in political discourse, and identifying its criteria and strategies.

Form the above, one can state that concealment is an act or statement that prevents others from obtaining knowledge of a fact. Therefore, it can be used as a strategy of deception or manipulation. On legal contexts, Bouvier (1874) presents concealment as misrepresenting information or a form of fraud in some cases. Precisely, the study attempts to answer the questions:

(1) From a pragmatic view, what is meant by concealment?

(2) What are the strategies of concealment?

(3) How do these strategies are triggered by the pragmatic devices?

It is hypothesized that concealment strategies are used as a means of persuasion; where the concealer controls information by following the way that suits his aims such as winning others admiration or getting out of an awkward situation. To achieve the aims of the current work, a model of analysis is developed as an eclectic model for the analysis of the data under study. This model is developed out of the pragmatic theories and concepts.

\section{Literature Review: Concealment}

Concealment is defined by Fyke (2014) as "withholding information in some instances". It is the mode of using 
language to withhold information for specific purposes. This act of hiding information is characterized and defined in terms of context and purpose; in other words, these two conditions-namely context and purpose - define the nature and the strategies of concealment.

Depending on both the context in which concealment is utilized and its purpose, McCornack (1992) introduced concealment as a strategy of manipulation, along with three other strategies which are namely the strategies of fabrication, distortion and equivocation.

Concealment is also defined by the ability to make something appear as different from what it actually is, or does not appear at all. Thus, it is a skill as well since it requires specific characteristics to assure the process of concealing.

\subsection{Concealment and Manipulation}

Both Ekman (1985) and Metts \& Hippensteele (1988) describe concealment as "preferred" form of deception compared to lying. Concealment is defined in terms of "incompleteness"; not telling the whole truth, whereas lying is the act of telling an "untruth".

As it is assumed by the researchers, concealment is a strategy of manipulation. Thus, the current paper remodifies manipulation strategies- mentioned by Baron's (2003); and Asya's (2013) categorizations-as strategies of concealment.

According to Baron (2003), deceptive manipulation includes outright lying, making false promises, and misleading the targets. Concealment, like deceptive manipulation, involves issuing lies and false assumptions to hide the truth. To conceal something, concealers may also go further and use strategies of browbeating, or threatening. Both Baron (2003) and Asya (2013) agree that the mental activity is essential here; the speaker can rely on the emotion of the target to manipulate, in this case to conceal intentions. Concealment, like manipulation, is characterized by eminent intention to conceal and usually this intentionality is hidden.

In his Information Manipulation Theory (henceforth IMT), McCornack et al. (2014, p. 350) refers to the Cooperative Principle and Grice's maxims to explain the effect of breaching them in deception. He (ibid) explains it as the consequence of violating Grice's maxims. From the same perspective, concealment is the result of, basically, violating quantity maxim; which results in giving less information than required. This is by means of intentionally withholding information.

\section{A Pragmatic View of Concealment}

The pragmatic dimension of concealment is covered throughout: (1) the pragmatic theories, such as breaching conversational maxims, pragma rhetorical devices, deictic expressions, and politeness theory. (2) Contextual factors; it is worth mentioning here that concealment cannot be detected from a set of obvious factors; context plays a crucial role in determining the appropriate concealment strategy that is suitable to certain aims.

\subsection{Breaching Conversational Maxims}

Breaching conversational maxims -Grice's maxims- is the main strategy of making concealment. Grice (1975, p. 45) assumes that, in interactions, people adhere to cooperative principles (henceforth CPs) that state "make your conversational contribution such as is required, at the stage at which it occurs by the accepted purpose or direction of the talk exchange in which you are engaged". These CPs can be redefined in terms of four maxims quality, quantity, relation, and manner. Breaching these maxims deliberately creates concealment, as stated below:

1) Flouting quantity maxim: the speaker uses inadequate information or gives less information than the situation requires for concealing or hiding something else.

2) Flouting quality maxim: the speaker, for the sake of hiding the truth, may rely on providing untrue information, like lies of fabrications.

3) Flouting relation maxim: the speaker uses irrelevant information in a talk to shed lights away from the main topic and concealing the required details

4) Flouting manner maxim: The speaker uses strategies of ambiguity to hide his intentions or some information.

\subsection{Pragma-Rhetorical Devices}

As far as concealment is concerned, the following rhetorical devices are utilized:

1) The Argumentation Appeals: Walton (2004) argues that in arguments these appeals are used for the sake of persuasion: (a) Ethos: as a rhetorical strategy in pragmatic, using ethos is the ability to persuade directly; this 
appeal is strongly related to the credibility of the speaker to be sincere and trustworthy, (b) Pathos: Walton (ibid, p. 171) states that emotions appeals are strong as they have the ability to make people actually do things. They can make an audience angry or proud. As such, this appeal can have power even over logical arguments; (c) Logos: this is the logical appeal as it is called by Walton (ibid, p. 332). To reach a certain aim in an argumentation, the speaker depends on logic and evidences.

2) Figures of speech: these are the "artful deviations" as defined by (Corbett, 1990), rhetorical figures of speech are considered as a way of producing a message with two meanings; the exact meaning or the literal one and the implied meaning. McQuarrie \& Mick (1996) classify them into two tropes:

1: Destabilization tropes: these tropes according to McQuarrie \& Mick (ibid, p. 433) are a means of saying more than what is said; the destabilization tropes rely on the audience to develop the implications. The current paper includes two destabilization tropes: Metaphor and Pun.

A) Metaphor: this figure of speech involves the case of using a word or phrase to describe something it does not literally denote, e.g., "This journal is a gem" (McGlone, 2007, p. 2).

B) Pun: it refers to the case of having myriad meanings. According to Bussmann (1996, p. 968), a pun is a matter of playing with words; the use of a word or phrase which holds two meanings at the same time.

2: Substitution tropes: in the substitution tropes "one says something other than what is meant, and relies on the recipient to make the necessary correction" (McQuarrie \& Mick, 1996, p. 433). As far as concealment is involved, the following tropes are considered:

A) Overstatement: (also known as Hyperbole): A rhetorical pragmatic strategy that referred to by Leech (1983) as "a case where the speaker's description is stronger than is warranted by the state of affairs described" (ibid, p. 145).

B) Understatement (also known as litotes): a figure of speech that includes utterance of "quantity, intensity, or seriousness of something that is less than what is objectively the case" in order to achieve the rhetorical impression (Cruse, 2006, p. 186).

C) Rhetorical questions: those questions are not asked for the purpose of eliciting an answer. Rhetorical questions are used intentionally for the sake of their rhetorical effect. This effect is usually to emphasize the speaker's point and arouse the hearers' attention.

\subsection{Deictic Expressions}

Depending on when, where and by whom, deictic expressions have a variety of shifting meanings. Their pragmatic meaning is determined by the context. Levinson (1983, p. 55) distinguishes between inclusive and exclusive "we"; where the first type includes both the speaker and the hearer, whereas the exclusive "we" excludes the speaker from the hearer. In political speeches, as asserted by Chilton \& Schaffner (1997, p. 216), deictic expressions are powerful means of legitimizing of the speaker's action; this is by using inclusive "we" to involve the hearer to the action and pretending that there is nothing hidden from the public.

\subsection{Politeness Theory}

The theory is introduced by Brown \& Levinson (1987), it states that "all competent adult members of a society have (and know each other to have) face" which is "the public self-image" (ibid, p. 61). They (ibid) present a number of positive and negative strategies of politeness. Only the strategies that are relevant to concealment are presented below:

1) Claim common ground: it states that both the speaker $(\mathrm{S})$ and hearer $(\mathrm{H})$ share the same wants, and values. Out of eight strategies, and as far as concealment is involved, only the following strategies are triggered:

1.1) Seek agreement: It allows $S$ either to stress his agreement with $H$ and therefore to satisfy H's desire to be "right". Repetition is another way to seek H's agreement; this is by repeating parts or all of what has been said (ibid, p. 112).

1.2) use in-group identity marker: $S$ uses the in-group identity to convey in group membership with the $H$. in this strategy, $\mathrm{S}$ can use in-group slangs, language or dialect, or address forms (Brown \& Levinson, ibid)

2) Convey that $S$ and $H$ are cooperative: this positive strategy includes:

2.1) Offer, make promises: offering is a polite- positive strategy as it indicates the good intentions of the speaker, and, thus, the speaker is not hiding or concealing anything.

2.2) Include both $\mathbf{S}$ and $\mathbf{H}$ in the activity: This is achieved by making use of inclusive "we" form, when $S$ 
really means "you" or "me", he can call upon the cooperative assumptions and thereby redress FTAs." (ibid, p. 127) Let's in English is considered as an inclusive "we" form.

2.3) Give reasons: To convey that both the $\mathrm{S}$ and $\mathrm{H}$ are cooperative; the speaker gives reasons for his actions to justify them.

\section{The Model of the Analysis}

The current paper aims at developing an eclectic model based on the pragmatic theories and ideas discussed earlier .The data chosen for analysis are considered as situations of concealment based on the criteria of: (a) breaching quantity maxim, (b) emotion criteria, and (c) strategies of manipulation. The model of analysis comprises three stages; each stage is characterized by certain concealment strategies and pragmatic strategies as well. The stages are: the issuing stage: at this stage, the speaker introduces the topic to be talked about or discussed. The first stage is characterized by employing the concealment strategies of: raising sense of fear, threat, sorrow and sympathy. Pragmatically, these strategies of concealment are made by breaching Grice's maxims, politeness strategies, the argument stage; concealment is manifested by giving false assumptions, false promises, outright lying, misleading, using specialized terms and direct accusations. Concealment is realized by means of breaching Grice maxims, politeness, and rhetorical devices as pragmatic strategies.

In the final stage, the speaker strengths the effects of the concealment by a means of seeking addressees' agreement, wearing down the other-side opinions, and browbeating. The pragmatic strategies followed here are breaching Grice's maxims, politeness, personal inclusive deixis, and rhetorical devices.

The model is schemed in Figure (1) below, and Table (1) represents the abbreviations used in the Figure.

Table 1. The symbolized components of the eclectic model

\begin{tabular}{ll}
\hline Components: strategies, sub-strategies & Symbols \\
\hline Breaching Conversational Maxims & BCMs \\
Pragma Rhetorical Devices & PRDs \\
Politeness Strategies & PSs \\
Deictic Expressions & DEs \\
Destabilization Tropes & DT \\
Substitution Tropes & ST \\
Argumentation Appeals & AAs \\
Figures of Speech & FsS \\
\hline
\end{tabular}

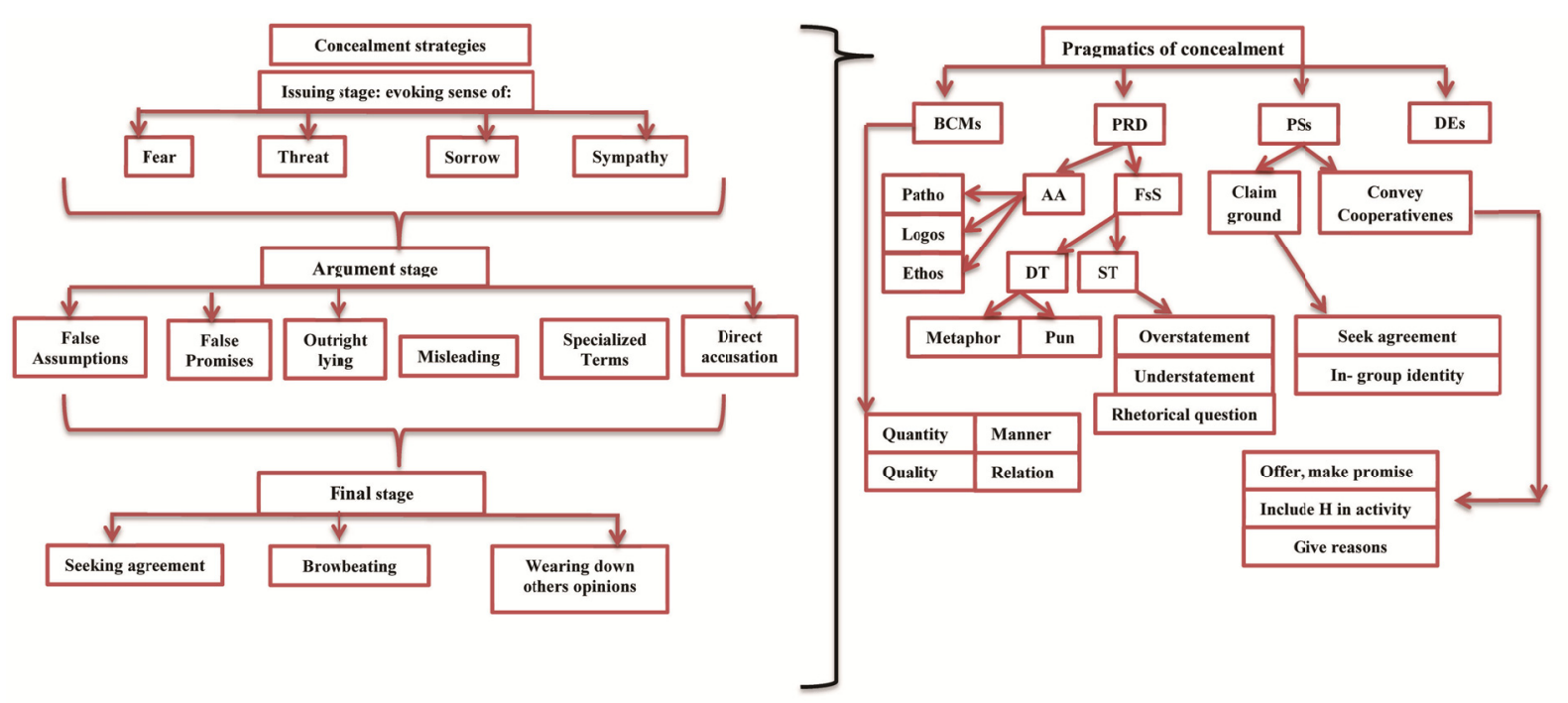

Figure 1. The developed analysis model

\subsection{Data and Analysis}

\section{A) Data Selection and Description}

The current work uses the speech of George Bush's Speech on Iraq, on March 18th, 2003 as the main data for 
analysis. The speech is downloaded from the internet from the website: https://www.theguardian.com. For the sake of analysis, the speech is presented as shorter extracts which are given the symbols of Extract (1), Extract (2), Extract (3) etc.

Bush's speech was an announcing of war against Iraq, under the pretext that Iraq developed Weapons of Mass Destruction (WMD) and refused to cooperate with UN inspectors of disarmament. The three different audiences, to which this speech was addressed, are the Americans, the International community, and Iraqis.

\section{B) The Analysis: Methods of Analysis}

To reach the aims of the current paper, the developed model which has been developed by the researchers and represented in Figure (1) will be the basic apparatus for analyzing the data of this work.

The criteria: the criteria used to judge that the speech involves concealment are the following:

(1) As stated earlier by Ekman (1985) and Metts \& Hippensteele (1987), concealment is characterized by "incompleteness"; in which the speaker is not telling the whole truth, but only half-truth. The part that suites the concealer's aims. From pragmatic point of view, breaching quantity maxim in particular is the first sign of hiding information; deceptive concealment involves issuing outright lying and making false assumptions. To assert using lies, the paper provides extracts announced latter by the same person (i.e., Bush) on 2006 that contradict with the first allegations.

(2) Emotional criteria: the speaker relies on eliciting an emotion, such as of sympathy, fear or even threat to steer the audience to the wanted direction. By doing so, the concealer makes the audience drift by their emotions to an area away from the one or the fact being concealed.

\subsection{Pragmatic Analysis}

\section{Extract (1)}

My fellow citizens, events in Iraq have now reached the final days of decision. For more than a decade, the United States and other nations have pursued patient and honorable efforts to disarm the Iraqi regime without war. That regime pledged to reveal and destroy all its weapons of mass destruction as a condition for ending the Persian Gulf War in 1991.

Since then, the world has engaged in 12 years of diplomacy. We have passed more than a dozen resolutions in the United Nations Security Council. We have sent hundreds of weapons inspectors to oversee the disarmament of Iraq. Our good faith has not been returned

The criteria: giving incomplete information justifications and, emotional criteria are used to steer the audience to agree on war; this is by raising emotions of sorrow that the efforts "has not been returned".

The issuing stage: the first stage is the stage where the speaker introduces his topic and claims "My fellow citizens, events in Iraq have now reached the final days of decision... war."

Concealment strategies are put out by means of raising the feeling of doing- all what can be done “...have pursued patient and honorable efforts to disarm the Iraqi regime without war." And raising the feeling of sorrow that "Our good faith has not been returned."

Pragmatic strategies: breaching Grice's maxim, particularly the quantity maxim by giving incomplete and vague information "the United States and other nations ..." without clarifying which "nations" he means and assuming that the audience already know this information and thus he doesn't go in any details for those "nations".

\section{The argument stage:}

That regime pledged to reveal and destroy all its weapons of mass destruction as a condition for ending the Persian Gulf War in 1991. Since then, the world has engaged in 12 years of diplomacy. We have passed more than a dozen resolutions in the United Nations Security Council. We have sent hundreds of weapons inspectors to oversee the disarmament of Iraq. Our good faith has not been returned

The concealment strategies used in the argument stage are manifested in giving false assumptions "That regime pledged to reveal and destroy all its weapons of mass destruction as a condition for ending the Persian Gulf War in 1991."; assuming that the regime has already these weapons.

The Pragmatic strategies used to create concealment are breaching the conversational maxims and politeness strategies which are presented by including the audience with the activity and by the strategy of giving reasons: "We have passed more than a dozen resolutions ...We have sent hundreds ..." Deictic expressions are used to 
indicate group membership "my fellow citizens... Our good faith has not been returned".

Pragma- rhetorical devices are used to conceal things as in the use of "logos" appeal in "For more than a decade, the United States and other nations have pursued patient and honorable efforts to disarm the Iraqi regime without war." Thus, by logic, it is the time of another effort to disarm Iraq, i.e., war. Substitutions troops like overstatement are triggered to raise the danger of Iraq and to justify the decision of launching war. Overstatement can be seen in: "We have passed more than a dozen resolutions in the United Nations Security Council. We have sent hundreds of weapons inspectors to oversee the disarmament of Iraq. Our good faith has not been returned".

The final stage: in this stage, Bush uses the strategies of seeking agreement, wearing down any opposite opinion and making decisions "We have sent hundreds of weapons inspectors to oversee the disarmament of Iraq. Our good faith has not been returned". Pragmatically, this is achieved by means of the rhetorical devices of hyperbole to assert the necessity and the seriousness of the topic "We have passed more than a dozen resolutions... We have sent hundreds of weapons inspectors to..." Other pragmatic strategies are issued by means of positive politeness strategies of using in-group identity marker and including audience in the activity "Our good faith has not been returned".

\section{Extract (2)}

The Iraqi regime has used diplomacy as a ploy to gain time and advantage. It has uniformly defied Security Council resolutions demanding full disarmament. Over the years, U.N. weapon inspectors have been threatened by Iraqi officials, electronically bugged, and systematically deceived. Peaceful efforts to disarm the Iraqi regime have failed again and again - because we are not dealing with peaceful men.

Intelligence gathered by this and other governments leaves no doubt that the Iraq regime continues to possess and conceal some of the most lethal weapons ever devised. This regime has already used weapons of mass destruction against Iraq's neighbors and against Iraq's people. The regime has a history of reckless aggression in the Middle East. It has a deep hatred of America and our friends. And it has aided, trained and harbored terrorists, including operatives of al Qaeda. The danger is clear: using chemical, biological or, one day, nuclear weapons, obtained with the help of Iraq, the terrorists could fulfill their stated ambitions and kill thousands or hundreds of thousands of innocent people in our country, or any other

The criteria: giving incomplete vague statements, raising feeling of threat and danger as well as to issuing false assumptions and outright lies "We are not dealing with peaceful men".

The issuing stage: this stage is triggered by means of raising the feeling of threat from the Iraqi regime "...to gain time and advantage. Over the years, U.N. weapon inspectors have been threatened by Iraqi officials, electronically bugged, and systematically deceived". Other concealment strategies are issued by means of justifying a decision (in this case declaring war); this is achieved by raising feeling of duty inside the audience and feeling of guilt and negative consequences if they -the audience- did not agree "we are not dealing with peaceful men", other concealment strategies are also exercised by giving false assumptions that "Peaceful efforts to disarm the Iraqi regime have failed again and again"; however, such false assumption does not assert that Iraq in fact possesses WMDs.

Pragmatic strategies are urged through breaching Grice's maxim of quality: "It has uniformly defied Security Council resolutions demanding full disarmament." through giving false allegations that Iraq does actually possess these weapons. Pragma-rhetoric devices are used through the destabilization trope of metaphor "The Iraqi regime has used diplomacy as a ploy to gain time and advantage." in which diplomacy is described as a ploy used by the Iraqi regime. Giving reasons is the politeness strategy used to justify war against Hussein's regime "because we are not dealing with peaceful men."

The argument stage: The strategies of concealment are: giving false assumptions and a set of allegations "the Iraq regime continues to possess and conceal some of the most lethal weapons ever devised... it has aided, trained and harbored terrorists, including operatives of al Qaeda. The danger is clear: using chemical, biological or, one day, nuclear weapons, obtained with the help of Iraq, the terrorists could fulfill their stated ambitions and kill thousands or hundreds of thousands of innocent people in our country, or any other". Outright lies are also issued to strength the war standpoint "...no doubt that the Iraq regime continues to possess".

The pragmatic strategies that are used are as the following: Argumentation appeals of "logos" "pathos" and "ethos" are manifested by: "Intelligence gathered by this and other governments leaves no doubt that the Iraq regime continues to possess and conceal some of the most lethal weapons ever devised", the "logos" appeal is 
used as a claim to justify an action like a "military coalition"; this claim is also asserted by means of "ethos" or the credibility of Bush as the president of the US to be trustworthy and sincere. This credibility gives him the right to use "no doubts" to assure the existence of WMDs. Finally the "pathos" is manifested by raising feeling of fear in the audience "Peaceful efforts to disarm the Iraqi regime have failed again and again — because we are not dealing with peaceful men".

Breaching quantity maxim is seen in "This regime has already used weapons of mass destruction against Iraq's neighbors and against Iraq's people." Where Bush continues with generalization and not giving full and accurate information; although Bush refers to using biological weapons against the Iranians and the Kurds respectively, but he breaches quantity maxim by giving less information than required- due to the fact that the speech is addressed to the ordinary public (whether the Americans, Iraqis, and the International community) who might not know such information- Manner maxim is also broken in the same way; not giving the information in a direct and clear manner by saying "Intelligence gathered by this and other governments" without clarifying what he means by the "other governments". Using deictic expression like "this government" and "this regime" identifies and classifies two groups to be involved in a conflict. However, Bush conceals other the parties involved in this war or conflict and he uses vague expressions like "other governments" or "our friends".

The final stage: Bush utilizes the strategies of seeking agreement, wearing out any opposite opinion, giving direct accusations by:

The regime has a history of reckless aggression in the Middle East. It has a deep hatred of America and our friends. And it has aided, trained and harbored terrorists, including operatives of al Qaeda. The danger is clear: using chemical, biological or, one day, nuclear weapons, obtained with the help of Iraq, the terrorists could fulfill their stated ambitions and kill thousands or hundreds of thousands of innocent people in our country, or any other

The pragmatic strategies used are: Breaching the maxim of Manner is clear in "It has a deep hatred of America and our friends"; where "our friends" is ambiguous and not clear. As such, he conceals information from his audience by not giving the details for those who might not understand what he is talking about. Substitution tropes are used by the device of overstatement to raise the feeling of danger "the terrorists could fulfill their stated ambitions and kill thousands or hundreds of thousands of innocent people in our country, or any other".

\section{Extract (3)}

The United States and other nations did nothing to deserve or invite this threat. But we will do everything to defeat it. Instead of drifting along toward tragedy, we will set a course toward safety. Before the day of horror can come, before it is too late to act, this danger will be removed. The United States of America has the sovereign authority to use force in assuring its own national security. That duty falls to me, as Commander-in-Chief, by the oath I have sworn, by the oath I will keep.Recognizing the threat to our country, the United States Congress voted overwhelmingly last year to support the use of force against Iraq. America tried to work with the United Nations to address this threat because we wanted to resolve the issue peacefully. We believe in the mission of the United Nations. One reason the UN was founded after the Second World War was to confront aggressive dictators, actively and early, before they can attack the innocent and destroy the peace. In the case of Iraq, the Security Council did act, in the early 1990s. Under Resolutions 678 and 687 - both still in effect-the United States and our allies are authorized to use force in ridding Iraq of weapons of mass destruction. This is not a question of authority, it is a question of will.

The criteria: Bush tries to evoke the emotion of sympathy "The United States and other nations did nothing to deserve or invite this threat" as well as presenting fake assumptions and imposing pressure on them in order to make them comply with his assumption

The issuing stage: "The United States and other nations did nothing to deserve or invite this threat". Bush starts by raising the feelings of sympathy and this is achieved pragmatically by using deictic expressions to involve his audience, in this case the Americans. "We will do everything to defeat it... we will set a course toward safety."

The argument stage: The concealment strategies are launched by: giving false assumptions and predictions "But we will do everything to defeat it. Instead of drifting along toward tragedy", concealment strategies are also expressed by means of giving false promises based on those false assumptions "we will set a course toward safety... by the oath I have sworn, by the oath I will keep..." Another strategy of concealment is by using specialized terms or jargons "Under Resolutions 678 and 687 " these resolutions are strictly specialized.

The pragmatic strategies of concealment are trigged through substitution trope of overstatement, which is used 
to express the size of the problem "Before the day of horror can come, before it is too late to act". Overstatement or hyperbole is also seen in stating "the United States Congress voted overwhelmingly last year to support the use of force against Iraq". The argumentative appeal is exercised by "ethos" appeal; that is to say, since he is the "Commander-in-Chief" then he has all the credibility to be believed. Breaching relation maxim (the relevance of disclosed information is expressed) is utilized in "America tried to work with the United Nations to address this threat because we wanted to resolve the issue peacefully. We believe in the mission of the United Nations. One reason the UN was founded after the Second World War was to confront aggressive dictators, actively and early, before they can attack the innocent and destroy the peace”, Bush uses irrelevant information by mentioning the UN, since he was basically talking about the US Congress, and he returned after that to talk about the Security Council. So, mentioning the UN is irrelevant.

The final stage: Bush utilizes the strategies of concealment by wearing down any opposite opinion, giving direct confirmation of power and browbeating "the United States and our allies are authorized to use force in ridding Iraq of weapons of mass destruction. This is not a question of authority; it is a question of will". From pragmatic point, this is achieved by means of breaching Grice maxims, practically quantity maxim and giving less information than required and manner maxim by giving vague and ambiguous expression like "our allies".

\section{Extract (4)}

Last September, I went to the U.N. General Assembly and urged the nations of the world to unite and bring an end to this danger. On November 8, the Security Council unanimously passed Resolution 1441, finding Iraq in material breach of its obligations, and vowing serious consequences if Iraq did not fully and immediately disarm.

Today, no nation can possibly claim that Iraq has disarmed. And it will not disarm so long as Saddam Hussein holds power. For the last four-and-a-half months, the United States and our allies have worked within the Security Council to enforce that Council's long-standing demands. Yet, some permanent members of the Security Council have publicly announced they will veto any resolution that compels the disarmament of Iraq. These governments share our assessment of the danger, but not our resolve to meet it. Many nations, however, do have the resolve and fortitude to act against this threat to peace, and a broad coalition is now gathering to enforce the just demands of the world. The United Nations Security Council has not lived up to its responsibilities, so we will rise to ours

The criteria: Bush conceals facts and hiding actual facts in Iraq, he employs the criteria of emotions to raise fear and sense of danger to impose his decision of attacking Iraq.

The issuing stage: Bush starts this stage by concealment strategies of raising feelings of fear and danger "Last September, I went to the U.N. General Assembly and urged the nations of the world to unite and bring an end to this danger" concealment is issued by the strategy of using specialized expressions that cannot be understood by all the audience "the Security Council unanimously passed Resolution 1441, finding Iraq in material breach". Pragmatic strategies of concealment are: breaching quantity maxim by not providing adequate information to assert and support the claim that Iraq possesses WMDs. the pragma-rhetoric device of overstatement is obvious in exaggerating the consequences of not disarming Iraq “ ... and vowing serious consequences if Iraq did not fully and immediately disarm"

The argument stage: in this stage, the speaker is using the strategies of concealment of: issuing false assumptions, outright lying and strict accusations "it will not disarm so long as Saddam Hussein holds power" as such he directly relates Hussein with the existence of weapons. However, it turns out later that even when Hussein was captured and executed, Iraq did not possess any weapon. Deictic expressions are used as pragmatic strategy that denotes a cutting line or difference between the US and other members of the Security Council "These governments share our assessment of the danger, but not our resolve to meet it". Breaching quantity maxim is utilized by not providing the required information and giving unclear expressions like "some permanent members" or "many nations". Politeness strategies are employed though the strategies of conveying that the speaker-representing the Americans- and the hearer-like the International community-are cooperative and involved in the same activity "Many nations, however, do have the resolve and fortitude to act against this threat to peace, and a broad coalition is now gathering to enforce the just demands of the world."

The final stage: Bush depends on the strategies of seeking agreement, wearing out any opposite opinion, and browbeating "The United Nations Security Council has not lived up to its responsibilities, so we will rise to ours". In this way, Bush imposes his standpoint by expressing that it is the duty call and a matter of responsibility that the US is ready to take. Pragmatically, this is expressed be the personal deixis "we". 


\section{Extract (5)}

Terrorists and terror states do not reveal these threats with fair notice, in formal declarations - and responding to such enemies only after they have struck first is not self-defense, it is suicide. The security of the world requires disarming Saddam Hussein now.

As we enforce the just demands of the world, we will also honor the deepest commitments of our country. Unlike Saddam Hussein, we believe the Iraqi people are deserving and capable of human liberty. And when the dictator has departed, they can set an example to all the Middle East of a vital and peaceful and self-governing nation.

The United States, with other countries, will work to advance liberty and peace in that region. Our goal will not be achieved overnight, but it can come over time. The power and appeal of human liberty is felt in every life and every land. And the greatest power of freedom is to overcome hatred and violence, and turn the creative gifts of men and women to the pursuits of peace. That is the future we choose. Free nations have a duty to defend our people by uniting against the violent. And tonight, as we have done before, America and our allies accept that responsibility. Good night, and may God continue to bless America

The criteria: Bush conceals facts and hiding actual facts in Iraq, he employs the criteria of emotions to raise fear and sense of danger and threat "Terrorists and terror states do not reveal these threats with fair notice, in formal declarations - and responding to such enemies only after they have struck first is not self-defense, it is suicide". By doing so, he imposes his decision of war.

The issuing stage: Bush starts this stage by concealment strategies of raising feelings of fear, browbeating and threat "Terrorists and terror states do not reveal these threats with fair notice, in formal declarations-and responding to such enemies only after they have struck first is not self-defense, it is suicide". The Pragmatic strategies of concealment are: breaching quantity maxim by not providing adequate information to assert and support the claim that Iraq possesses WMDs. or to assert that the security of the world is jeopardized because of Hussein. The pragma-rhetoric device of overstatement is utilized in exaggerating the threat coming from Hussein "The security of the world requires disarming Saddam Hussein now" and by doing so, the stands of war against Iraq gets stronger.

The argument stage: in this stage, Bush uses the strategies of concealment of: issuing false assumptions, outright lying and strict accusations. These are triggered by The pragma-rhetoric device of substitution trope of overstatement "The security of the world requires disarming Saddam"; destabilization trope of metaphor " And when the dictator has departed, they can set an example to all the Middle East of a vital and peaceful and self-governing nation." where Hussein is being represented as dictator and, hence, a source of danger; the politeness strategies of conveying the speaker is cooperating with the audience by means of including the audience in the activity "we will also honor the deepest commitments of our country".

The final stage: Bush depends on the strategies of seeking agreement, browbeating, and wearing down any opposite opinion "And tonight, as we have done before, America and our allies accept that responsibility". Pragmatically, this is expressed be the personal deixis "our" in: "Our goal will not be achieved overnight, but it can come over time" and "we" as in: "That is the future we choose". By using this, he uses the politeness strategy of including the audience in the activity, and giving a promise of "... and turn the creative gifts of men and women to the pursuits of peace".

\section{Conclusion}

The research asserted the hypothesis set by the researchers; concealment strategies are used in Bush's speech to persuade his audience about the decision of war against Iraq. The speaker, by means of concealment strategies, controls the flow of information in accordance with his aims.

The pragmatic analysis shows that concealment strategies are issued by means of (1) using the emotional criteria via evoking the feelings of threat, duty, sorrow, sympathy, doing- all what can be done. (2) Using deceptive manipulation strategies like giving false assumptions, false promises, justifications, wearing down opposite opinions, direct accusations, outright lies, seeking agreement, browbeating and using specialized terms.

The analysis also shows that these strategies are pragmatically created by means of breaching Grice's maximsparticularly the quantity maxim-, the use of pragma-rhetorical devices, deictic expressions and positive politeness strategies.

\section{References}

Asya, A. (2013). Linguistic Manipulation: Definition and Types. International Journal of Cognitive Research Science, Engineering and Education (IJCRSEE). Retrieved from 
http://ijcrsee.com/index.php/IJCRSEE/article/view/128

Baron, M. (2003). Manipulativeness. Proceding and Addresses of the American Philosophical Associasion, 77(2), 37-54. https://doi.org/10.2307/3219740

Brown, P., \& Levinson, S. C. (1987). Politeness: Some Universals in Language Usage. Cambridge: Cambridge University Press.

Chilton, P., \& Schaffner, C. (1997). Discourse Pragmatics. In T. Van Dijk (Ed.), Discourse as Social Interaction. London: Sage.

Clark, H. H. (1992). Areas of Language Use. London: the University of Chicago press.

Cruse, A. (2006). A Glossary of Semantics and Pragmatics. Edinburgh: University Press Ltd.

Ekman, P (1985). Telling Lies: Clues to Deceit in the Marketplace, Marriage, and Politics. New York W.W. Norton.

Fyke, J (2014). Words as Camouflage. Research at Marquette. Retrieved from https://medium.com/research-at-marquette/words-as-camouflage-b911a206edff

Grice, H. P. (1975). Logic and Conversation. In P. Cole \& J. I. Margon (Eds.), Speech Acts. New York: New York Academic Press.

Harris, P. A. (2005). A Handbook of Rhetorical Devices. Retrieved from http://www.Virtuasalt.com/rhetoric.htm

Leech, G. (1983). Principles of Pragmatics. London: Longman.

Levinson, S. (1983). Pragmatics. Cambridge: Cambridge University Press.

McCornack, S. (1992). Information Manipulation Theory. Communication Monographs, 59, 1-16. https://doi.org/10.1080/03637759209376245

McCornack, S., Morrison, K., Paik, J. E., Wisner, A. M. \& Zhu, X. (2014). Information Manipulation Theory 2: A Propositional Theory of Deceptive Discourse Production. Journal of Language and Social Psychology, 33(4), 348-377. https://doi.org/10.1177/0261927X14534656

McQuarrie, E., \& Mick, D. (1996). Figures of Rhetoric. New Jersey: John Wiley \& Sons, Inc.

Metts, S., \& Hippensteele, S. (1988). Characteristics of Deception in Close Relationships. Advances in Interpersonal Communication Research, 33-50.

Schröter, M. (2013). Silence and Concealment in Political Discourse. Amsterdam: John Benjamins Publishing Company. https://doi.org/10.1075/dapsac.48

\section{Copyrights}

Copyright for this article is retained by the author(s), with first publication rights granted to the journal.

This is an open-access article distributed under the terms and conditions of the Creative Commons Attribution license (http://creativecommons.org/licenses/by/4.0/). 